\title{
Działanie krioterapii ogólnoustrojowej i kinezyterapii na ciśnienie tętnicze
}

\section{The effect of systemic cryotherapy and kinesiotherapy on blood pressure}

\author{
Żaneta Ciosek ${ }^{1}$, Adam Drozd $^{2}$, Aleksandra Szylińska', Hanna Mosiejczuk¹, Iwona Rotter ${ }^{1}$ \\ ${ }^{1}$ Pomorski Uniwersytet Medyczny w Szczecinie, Samodzielna Pracownia Rehabilitacji Medycznej, ul. Żołnierska 54, 71-210 Szczecin \\ ${ }^{2}$ Miejski Ośrodek Sportu, Rekreacji i Rehabilitacji, ul. Wt. Szafera 7, 71-245 Szczecin \\ $\triangle$ ciosekzaneta@gmail.com
}

\begin{abstract}
Introduction: Cryotherapy is a short time usage of temperatures below $-100^{\circ} \mathrm{C}$ to make a physiological reaction to cold. The first cryotherapy in the world took place in 1978 thanks to Toshiro Yamauchi and his team who performed cryotherapy treatment on patients with Ankylosing spondylitis.

The aim of the study was to determine the influence of the systemic cryotherapy on the reduction of blood pressure in patients with hypertension and without it.

Materials and methods: For this study it was examined 45 patients, including 36 women (80\%) and 9 men (20\%). All patients were undergoing 10 systemic cryotherapy treatments. $45 \%$ of them were also diagnosed with hypertension. Time of $1^{\text {st }}$ treatment was 1 minute, $5^{\text {th }}-$ about 2 minutes, $10^{\text {th }}-$ about
\end{abstract}

3 minutes. After cryotherapy each patient was directed to the kinesiotherapy treatment. Measurement of blood pressure (systolic and diastolic) patients was performed 3 times: $1^{\text {st }}$ day, $5^{\text {th }}$ and the $10^{\text {th }}$ day: before entering the chamber, immediately after the exit from the chamber and after 15 minutes of exercise (within physiotherapy).

Results and conclusions: In patients with hypertension demonstrated the positive effect of cryotherapy and physiotherapy on blood pressure systolic and diastolic. In the group of patients with hypertension had significantly higher systolic blood pressure $(\mathrm{p}<0.05)$ and diastolic $(\mathrm{p}<0.001)$ before treatment, compared with patients without hypertension. Cryotherapy and physiotherapy has a positive effect on blood pressure.

Key words: cryotherapy; kinesiotherapy; blood pressure.

\begin{abstract}
ABSTRAKT
Wstęp: Krioterapia to krótkotrwałe wykorzystanie temperatur poniżej $-100^{\circ} \mathrm{C}$ w celu spowodowania fizjologicznej reakcji na zimno. Pierwsza na świecie kriokomora powstała w $1978 \mathrm{r}$. dzięki prof. Toshiro Yamauchi, który wraz z zespołem naukowym przeprowadził krioterapię ogólnoustrojową u pacjentów ze zdiagnozowanym zesztywniającym zapaleniem stawów.

Celem pracy była ocena wpływu krioterapii ogólnoustrojowej na redukcję ciśnienia tętniczego krwi u pacjentów z ustabilizowanym nadciśnieniem tętniczym oraz bez nadciśnienia.

Materiały i metody: Grupę badaną stanowiło 45 pacjentów: 36 kobiet (80\%) i 9 mężczyzn (20\%), którzy zostali poddani 10 zabiegom krioterapii ogólnoustrojowej. Prawie połowa pacjentów (45\%) miała rozpoznane nadciśnienie tętnicze. Czas trwania 1. zabiegu wynosił $1 \mathrm{~min}, 5$. - $2 \mathrm{~min}$, a 10. - 3 min. Po krioterapii ogólnoustrojowej pacjenci brali udział w kinezyterapii. Pomiar
\end{abstract}

ciśnienia tętniczego krwi (ciśnienie skurczowe i rozkurczowe) pacjentów został wykonany 3-krotnie: w 1., 5. i 10. dniu: tuż przed wejściem do kriokomory, bezpośrednio po wyjściu z kriokomory oraz po 15 min ćwiczeń (w ramach kinezyterapii).

Wyniki i wnioski: W grupie pacjentów chorujących na nadciśnienie tętnicze wykazano pozytywny wpływ stosowania krioterapii ogólnoustrojowej i kinezyterapii na wartości ciśnienia tętniczego skurczowego i rozkurczowego. W badanej grupie pacjenci leczący się z powodu nadciśnienia tętniczego mieli istotne statystycznie wyższe wartości ciśnienia tętniczego skurczowego $(\mathrm{p}<0,05)$ oraz rozkurczowego $(\mathrm{p}<0,001)$ przed terapią w porównaniu z pacjentami bez nadciśnienia tętniczego. Krioterapia ogólnoustrojowa i kinezyterapia wykazują pozytywny wpływ na wartości ciśnienia tętniczego.

Słowa kluczowe: krioterapia; kinezyterapia; ciśnienie tętnicze.

\section{WSTĘP}

Krioterapią nazywa się krótkotrwałe wykorzystanie temperatur poniżej $-100^{\circ} \mathrm{C} w$ celu spowodowania fizjologicznej reakcji na zimno [1]. Zabieg ten można wykonywać: 1) na wybraną część ciała (krioterapia miejscowa), 2) na całe ciało pacjenta, który znajduje się w komorze kriogenicznej (krioterapia ogólnoustrojowa) [2].

Pierwsza na świecie kriokomora powstała w 1978 r. Yamauchi i wsp. po raz pierwszy przeprowadzili krioterapię ogólnoustrojową u pacjentów ze zdiagnozowanym zesztywniającym zapaleniem stawów [3]. Stosowanie temperatur kriogenicznych działających ogólnoustrojowo wywołuje w ciele człowieka wiele wartościowych reakcji fizjologicznych, które w konsekwencji dają efekt: przeciwbólowy (zwolnienie przewodnictwa we włóknach czuciowych oraz czynnościowe wyłączenie 
poprzez niskie temperatury receptorów czuciowych i ich połączeń z proprioreceptorami), przeciwobrzękowy i przeciwzapalny, nerwowo-mięśniowy, krążeniowy, hormonalny (wzrost wydzielania beta-endorfin) oraz metaboliczny (wzrost stężenia bradykininy i angiotensyny w zmienionych zapalnie tkankach oraz obniżenie stężenia histaminy i mleczanów) [4, 5, 6].

Reakcje biologiczne połączone $\mathrm{z}$ działaniem zimna na organizm przebiegają $w$ dwóch etapach. W pierwszym następuje skurcz naczyń, zmniejszenie krążenia tętniczego, żylnego i chłonki. Ponadto uruchomione są odruchy obronne, które pozwalają zminimalizować utratę ciepła. W drugim etapie obserwuje się rozszerzenie naczyń krwionośnych i przekrwienie tkanek.

Krioterapia jest nieodzownym składnikiem tzw. kriorehabilitacji, którą łączy się wraz z kinezyterapią. Zastosowanie kinezyterapii tuż po zabiegu krioterapii ogólnoustrojowej powoduje utrzymanie się korzystnych efektów leczenia niskimi temperaturami [7].

Zabiegi z wykorzystaniem zimna znajdują zastosowanie w wielu schorzeniach: chorobach narządu ruchu, chorobach zwyrodnieniowych (stawów obwodowych i kręgosłupa), zmianach przeciążeniowych i zapalnych, chorobach układu nerwowego ze spastycznością, stwardnieniu rozsianym oraz chorobie Parkinsona. Ze względu na korzystne działanie ogólnoustrojowe krioterapia stosowana jest także w odnowie biologicznej i medycynie sportowej. Przeciwwskazaniem do krioterapii ogólnoustrojowej są m.in. choroby nowotworowe, wady serca, niewydolność krążenia czy nieuregulowane nadciśnienie tętnicze [8, 9]. Wiele wyników badań naukowych potwierdza fakt, iż podwyższone ciśnienie tętnicze jest przeciwwskazaniem do wykonania krioterapii ogólnoustrojowej. Warto dodać, że nie obserwuje się negatywnego wpływu tego zabiegu na zachowanie ciśnienia tętniczego krwi u osób z niepodwyższonym ciśnieniem [10].

Leczenie zimnem odbywa się $\mathrm{w}$ kriokomorze o temperaturze od -120 do $-130^{\circ} \mathrm{C}$. Pacjent z suchą skórą, ubrany w strój kąpielowy, skarpetki, drewniane buty i ochraniacze na nos, usta i uszy, porusza się spokojnym krokiem przez maks. 3 min. Utrzymuje przy tym kontakt wzrokowy z lekarzem i/lub fizjoterapeutą, który interweniuje $\mathrm{w}$ razie wystąpienia reakcji niepożądanych.

Po każdym wyjściu z kriokomory oraz zmianie obuwia i stroju wykonuje się ćwiczenia pod okiem fizjoterapeuty, w skład których wchodzą: ćwiczenia czynne, bierne, czynno-bierne czy izometryczne. W ramach leczenia należy zrealizować co najmniej 10 zabiegów, w niektórych przypadkach 2-3 razy dziennie $[7,11]$.

Celem badań była ocena wpływu krioterapii ogólnoustrojowej na redukcję ciśnienia tętniczego krwi u pacjentów z ustabilizowanym nadciśnieniem tętniczym oraz bez nadciśnienia. krioterapii ogólnoustrojowej (z 2-dniowymi odstępami) z powodu różnorodnych schorzeń układu ruchu (z wykluczeniem chorób zapalnych) lub w ramach odnowy biologicznej bez rozpoznanego schorzenia. Ponadto w skierowaniu uwzględniono informację na temat innych chorób współistniejących. U 20 osób (44\%) odnotowano nadciśnienie tętnicze (skurczowe $\geq 140$ i/lub rozkurczowe $\geq 90$ ), które zostało zdiagnozowane co najmniej 10 lat wcześniej (od daty pierwszego zabiegu). Nadciśnienie tętnicze było leczone i unormowane farmakologicznie (inaczej pacjent byłby zdyskwalifikowany z zabiegu). Przyjmowanym lekiem wśród grupy badanej był Concor lub Bisocard. W badaniach posłużono się pomiarami całej populacji osób, które brały udział w zabiegu, a grupę kontrolną tworzyły osoby bez zdiagnozowanego nadciśnienia tętniczego. Grupę I stanowiły osoby z nadciśnieniem tętniczym, a grupę II pacjenci nieleczący się z powodu nadciśnienia tętniczego. Badania zostały przeprowadzone w kriokomorze firmy Metrum CryoFlex-Arctica (Polska) na Oddziale Rehabilitacji Samodzielnego Publicznego Wojewódzkiego Szpitala Zespolonego w Szczecinie. Do pomiarów ciśnienia tętniczego krwi pacjentów użyto aparatu Omron M1 Classic (dokładność pomiaru $\pm 3 \mathrm{mmHg}$ ). Klasa urządzenia pomiarowego była wystarczająca do celu analizy i sposobu obróbki danych (estymacja średniej). Badania były prowadzone od stycznia do marca $2012 \mathrm{r}$.

Czas trwania 1. zabiegu wynosił $1 \mathrm{~min}, 5 .-2 \mathrm{~min}$, a 10. - 3 min. Temperatura w kriokomorze w trakcie serii zabiegów wynosiła $-120^{\circ} \mathrm{C}$. Po leczeniu krioterapią ogólnoustrojową pacjenci wzięli udział w kinezyterapii składającej się z ćwiczeń na bieżni, ergometrze, cykloergometrze czy orbitreku (o umiarkowanym stopniu natężenia). Osoby poddane badaniu oprócz leczenia zimnem nie przyjmowały żadnych innych zabiegów fizykalnych, ani nie zmieniały stosowanego dotychczas leczenia farmakologicznego.

Pomiar ciśnienia tętniczego krwi (ciśnienie skurczowe i rozkurczowe) pacjentów został wykonany 3-krotnie, w 1., 5. i 10. dniu (ostatni dzień zabiegowy). W każdym z tych dni pomiar został przeprowadzony 3 razy - tuż przed wejściem do kriokomory, bezpośrednio po wyjściu z kriokomory oraz po 15 min ćwiczeń (w ramach kinezyterapii).

Analizę statystyczną przeprowadzono z użyciem elementów statystki opisowej (głównie średnie odchylenia standardowe, minimum i maksimum). Do analizy wykorzystano program Statistica 10. Do statystycznej oceny rozkładu badanej zmiennej użyto testu W Shapiro-Wilka. Większość badanych zmiennych miała rozkład normalny, dlatego do zbadania związku pomiędzy wartościami ciśnienia tętniczego a pacjentami chorującymi lub niechorującymi na nadciśnienie wykorzystano głównie test t-Studenta dla prób niezależnych lub test U Manna-Whitneya, jeśli rozkład odbiegał od normy. Istotność statystyczna została określona przy wartości $\mathrm{p}<0,05$.

\section{WYNIKI}

Średnie wartości oraz odchylenia standardowe wraz z minimum i maksimum z podziałem na pacjentów leczących się
Grupę badaną stanowiło 45 pacjentów: 36 kobiet (80\%) i 9 mężczyzn (20\%), którzy otrzymali skierowanie na 10 zabiegów 
z powodu nadciśnienia tętniczego i niechorujących na nadciśnienie tętnicze przedstawiono $\mathrm{w}$ tabeli 1. Istotne statystycznie różnice $(\mathrm{p}<0,05)$ w badanej grupie zaobserwowano względem wieku, a wśród starszych pacjentów obserwowano znamiennie częściej nadciśnienie tętnicze.

$\mathrm{W}$ badanej grupie pacjenci leczący się z powodu nadciśnienia tętniczego mieli istotne statystycznie wyższe wartości ciśnienia tętniczego skurczowego $(\mathrm{p}<0,001)$ oraz rozkurczowego $(\mathrm{p}<0,001)$ przed terapią w porównaniu z pacjentami bez nadciśnienia tętniczego (tab. 2). Po serii zabiegów również zaobserwowano istotne statystycznie różnice średnich wartości ciśnienia tętniczego pacjentów z nadciśnieniem i bez nadciśnienia $(\mathrm{p}=0,03)$.

W obydwu badanych grupach średnia wartość ciśnienia tętniczego skurczowego przed zabiegami wynosiła $140 \mathrm{mmHg}$, a po serii zabiegów zaobserwowano istotny statystycznie $(\mathrm{p}<0,001)$ spadek ciśnienia skurczowego do wartości $129 \mathrm{mmHg}$. Podobny wynik stwierdzono w przypadku ciśnienia tętniczego rozkurczowego, odnotowując istotne statystycznie $(\mathrm{p}<0,001)$ obniżenie średniej wartości sprzed rehabilitacji (88 $\mathrm{mmHg}$ ) i po rehabilitacji $(78 \mathrm{mmHg}$ ).

W grupie pacjentów chorujących na nadciśnienie tętnicze wykazano pozytywny wpływ krioterapii ogólnoustrojowej i kinezyterapii na wartości ciśnienia tętniczego skurczowego i rozkurczowego. Przed zabiegami średnie wartości ciśnienia tętniczego skurczowego utrzymywały się na poziomie $150 \mathrm{mmHg}$, a rozkurczowego - $92 \mathrm{mmHg}$. Z kolei po serii zabiegów zaobserwowano istotny statystycznie spadek ciśnienia skurczowego ( $\mathrm{p}<0,001)$ do $137 \mathrm{mmHg}$ i rozkurczowego $(\mathrm{p}<0,001)$ do $81 \mathrm{mmHg}$.

Wśród pacjentów bez nadciśnienia tętniczego również zaobserwowano pozytywny efekt stosowania krioterapii ogólnoustrojowej i kinezyterapii na wartości ciśnienia tętniczego. Średnia wartość ciśnienia skurczowego przed krioterapią wynosiła $132 \mathrm{mmHg}$, a po zakończeniu wszystkich serii zabiegów spadła do $123 \mathrm{mmHg}(\mathrm{p}<0,001)$. Ponadto przed zabiegami średnia wartość ciśnienia rozkurczowego wynosiła $84 \mathrm{mmHg}$ i po rehabilitacji zanotowano istotny statycznie spadek $(\mathrm{p}<0,001)$ do wartości $76 \mathrm{mmHg}$.

TABELA 1. Statystyka opisowa charakteryzująca badaną grupę

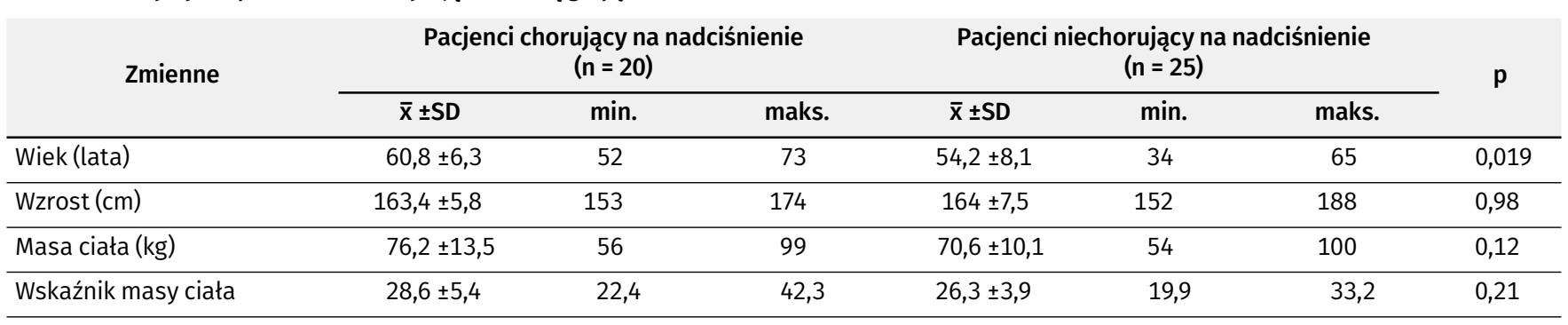

TABELA 2. Analiza zmian wartości ciśnienia tętniczego w zależności od dnia zabiegowego u pacjentów bez nadciśnienia tętniczego oraz z leczonym nadciśnieniem tętniczym

\begin{tabular}{|c|c|c|c|c|c|c|c|c|}
\hline \multirow{2}{*}{ Wartości ciśnienia tętniczego } & & \multicolumn{3}{|c|}{$\begin{array}{l}\text { Pacjenci chorujący na nadciśnienie } \\
\qquad(\mathrm{n}=20)\end{array}$} & \multicolumn{3}{|c|}{$\begin{array}{l}\text { Pacjenci niechorujący na nadciśnienie } \\
\qquad(\mathrm{n}=25)\end{array}$} & \multirow[t]{2}{*}{$p$} \\
\hline & & $\overline{\mathbf{x}} \pm S D$ & $\min$. & maks. & $\overline{\mathrm{x}} \pm \mathrm{SD}$ & $\min$. & maks. & \\
\hline \multirow{2}{*}{ RR przed 1. wejściem do kriokomory } & $\mathrm{S}$ & $150 \pm 12,1$ & 125 & 163 & $132 \pm 7,3$ & 114 & 140 & $<0,001$ \\
\hline & $\mathrm{D}$ & $92 \pm 6,3$ & 82 & 102 & $84 \pm 7,7$ & 67 & 90 & 0,003 \\
\hline RR bezpośrednio po 1. wyjściu z kriokomory & $\mathrm{S}$ & $154 \pm 14,6$ & 123 & 180 & $127 \pm 7,5$ & 111 & 138 & $<0,001$ \\
\hline \multirow{2}{*}{ RR po 15 min ćwiczeń (I seria) } & $\mathrm{S}$ & $143 \pm 13,2$ & 119 & 165 & $120 \pm 13,5$ & 107 & 138 & $<0,001$ \\
\hline & $\mathrm{D}$ & $86 \pm 9,4$ & 72 & 100 & $79 \pm 7,9$ & 61 & 97 & 0,056 \\
\hline \multirow{2}{*}{ RR przed 2. wejściem do kriokomory } & $\mathrm{S}$ & $143 \pm 12$ & 119 & 157 & $125 \pm 10,6$ & 110 & 139 & $<0,001$ \\
\hline & $\mathrm{D}$ & $87 \pm 7,2$ & 75 & 97 & $82 \pm 9,5$ & 61 & 92 & 0,01 \\
\hline RR bezpośrednio po 2. wyjściu z kriokomory & $\mathrm{S}$ & $148 \pm 16,4$ & 119 & 188 & $124 \pm 10,7$ & 105 & 145 & $<0,001$ \\
\hline \multirow{2}{*}{ RR po 15 min ćwiczeń (II seria) } & $\mathrm{S}$ & $142 \pm 13,4$ & 122 & 165 & $121 \pm 10,8$ & 107 & 136 & $<0,001$ \\
\hline & $\mathrm{D}$ & $84 \pm 7,6$ & 71 & 97 & $77 \pm 9,3$ & 54 & 90 & 0,02 \\
\hline \multirow{2}{*}{ RR przed 3. wejściem do kriokomory } & $\mathrm{S}$ & $140 \pm 10,9$ & 125 & 157 & $123 \pm 8,9$ & 105 & 137 & $<0,001$ \\
\hline & $\mathrm{D}$ & $87 \pm 7,4$ & 72 & 99 & $79 \pm 8,2$ & 67 & 98 & 0,019 \\
\hline \multirow{2}{*}{ RR bezpośrednio po 3. wyjściu z kriokomory } & $\mathrm{S}$ & $147 \pm 9$ & 134 & 167 & $123 \pm 6,7$ & 108 & 140 & $<0,001$ \\
\hline & D & $83 \pm 7,1$ & 72 & 96 & $77 \pm 8,2$ & 61 & 97 & 0,01 \\
\hline \multirow{2}{*}{ RR po 15 min ćwiczeń (III seria) } & $\mathrm{S}$ & $137 \pm 11,2$ & 117 & 156 & $123 \pm 7,9$ & 111 & 139 & $<0,001$ \\
\hline & $\mathrm{D}$ & $81 \pm 7,1$ & 68 & 92 & $76 \pm 7,5$ & 62 & 90 & 0,03 \\
\hline
\end{tabular}

RR - ciśnienie tętnicze; S - ciśnienie skurczowe (Systole); D - ciśnienie rozkurczowe (Diastole) 


\section{DYSKUSJA}

Temperatury kriogeniczne wywołują wiele reakcji o leczniczym efekcie dla organizmu. Publikowane są zróżnicowane doniesienia na temat wpływu krioterapii ogólnoustrojowej na ciśnienie tętnicze, zarówno u osób zdrowych, jak i z nadciśnieniem.

Badania przedstawione w niniejszej pracy dotyczą wpływu krioterapii ogólnoustrojowej z następową kinezyterapią na zachowanie się ciśnienia tętniczego krwi. W badaniach własnych zaobserwowano pozytywny wpływ stosowania krioterapii ogólnoustrojowej oraz kinezyterapii na wartości ciśnienia tętniczego skurczowego i rozkurczowego w grupie pacjentów chorujących na nadciśnienie tętnicze. Ponadto w badanej grupie pacjenci leczący się z powodu nadciśnienia tętniczego mieli istotnie statystycznie wyższe wartości ciśnienia tętniczego skurczowego $(p<0,05)$ oraz rozkurczowego $(\mathrm{p}<0,001)$ przed terapią w porównaniu do pacjentów bez nadciśnienia tętniczego.

Podobne badania zostały wykonane przez Machalskiego i wsp., którzy przebadali 54 pacjentów z oddziału rehabilitacji w Tczewie, uczestniczących w zabiegach krioterapii ogólnoustrojowej. Osoby chorujące na nadciśnienie tętnicze charakteryzowały się istotnie wyższym ciśnieniem (skurczowym i rozkurczowym) niż grupa osób zdrowych we wszystkich pomiarach $(\mathrm{p}<0,05)$, co potwierdzają wyniki własne. Ponadto nie stwierdzono istotnego wzrostu ciśnienia tętniczego w wyniku zastosowania czynnika temperatur kriogenicznych, mierzonego po symulacji ruchu wykonywanego w kriokomorze oraz po zabiegu - brak obiektywnego ryzyka stosowania zabiegu krioterapii ogólnoustrojowej u pacjentów z uregulowanym nadciśnieniem tętniczym [12].

W kolejnych badaniach wzięły udział 2 grupy: osoby zdrowe i chorujące na reumatoidalne zapalenie stawów. Celem pracy była ocena zastosowania krioterapii ogólnoustrojowej na wartości ciśnienia tętniczego krwi, częstości akcji serca, zapisy elektrokardiograficzne z całodobowym monitorowaniem EKG metodą Holtera oraz wskaźniki hemodynamiczne serca. Wyniki badań nie wykazały znamiennych statystycznie różnic po jednym zabiegu w kriokomorze oraz po serii 5 i 10 zabiegów [13, 14].

W piśmiennictwie opisano badania dostarczające sprzecznych wniosków. Odmienne wyniki przedstawili np. Fricke i wsp., opisując fizjologiczne skutki krioterapii ogólnoustrojowej, jak również sygnalizując niewielki wzrost ciśnienia krwi obserwowany u pacjentów z prawidłowym ciśnieniem tętniczym [15]. Westerlund i wsp. opisali wyniki badań dotyczące wpływu długotrwałej (3-miesięcznej) krioterapii ogólnoustrojowej na ciśnienie krwi mężczyzn i kobiet poddanych tym zabiegom; wykazano czasowy wzrost zarówno ciśnienia skurczowego, jak i rozkurczowego [16]. Taghinejad analizował zmiany wartości ciśnienia krwi i tętna po zastosowaniu krioterapii całego ciała na grupie 684 pacjentów w różnym przedziale wiekowym. Na podstawie wyników stwierdzono, że ciśnienie tętnicze nieznacznie wzrosło we wszystkich grupach badanych średnio o $10 \mathrm{~mm} \mathrm{Hg}$ (skurczowe) i $5 \mathrm{~mm} \mathrm{Hg}$ (rozkurczowe). Zaobserwowano również, że u osób z nadciśnieniem labilnym, nadciśnieniem utrwalonym leczonym farmakologicznie lub nieleczonym może dochodzić do znacznego wzrostu ciśnienia krwi [12].

Zastosowanie temperatur kriogenicznych zarówno u osób zdrowych, jak i u pacjentów cierpiących na liczne schorzenia ma pozytywny wpływ na fizjologiczne i biochemiczne wskaźniki w organizmie człowieka [17].

\section{WNIOSKI}

Pozytywny wpływ na wartości ciśnienia tętniczego wykazuje działanie krioterapii ogólnoustrojowej i kinezyterapii. Wśród pacjentów chorujących na nadciśnienie tętnicze stosowanie krioterapii ogólnoustrojowej i kinezyterapii istotnie obniża wartości ciśnienia skurczowego i rozkurczowego po serii zabiegów. Podobne efekty uzyskuje się wśród pacjentów nieleczących się z powodu nadciśnienia tętniczego; $\mathrm{w}$ tej grupie również zauważa się spadek wartości ciśnienia tętniczego skurczowego i rozkurczowego pod wpływem działania krioterapii ogólnoustrojowej i kinezyterapii.

\section{PIŚMIENNICTWO}

1. Kopacz Ł, Ciosek Ż, Kot K, Lietz-Kijak D, Kijak E, Śliwiński Z, et al. Wartość terapeutyczna krioterapii miejscowej w leczeniu objawowym pacjentów z zespołem bólowym stawu barkowego. Fizjoter Pol 2015;4:54-62.

2. Suszko R. Krioterapia ogólnoustrojowa. Rehab Med 2003;7(2):63-75.

3. Księżopolska-Pietrzak K. Krioterapia w leczeniu chorób reumatycznych. Ortop Traumatol Rehab 2000;2(5):66-9.

4. Miller E. Porównanie skuteczności działania krioterapii miejscowej i ogólnoustrojowej w bólu przewlekłym. Fizjoter Pol 2006;6:27-31.

5. Sieroń A, Rykaczewska-Czerwińska M, Klimkiewicz T, Jakrzewska H, Jagodziński L, Birkner E, et al. Antinociceptive effect in rats induced by the cooling of their whole body. Acta Bio-Opt Inform Med 2002;8: 153-5.

6. Wojtecka-Lukasik E, Księżopolska-Orlowska K, Gaszewska E, Krasowicz-Towalska O, Rzodkiewicz P, Maślińska D, et al. Cryotherapy decreases histamine levels in the blood of patients with rheumatoid arthritis. Inflamm Res 2010;59:253-3.

7. Stanek A, Sieroń A. Współczesna krioterapia ogólnoustrojowa w odnowie biologicznej. Ann Acad Med Siles 2012;66(4):64-70.

8. Stanek A, Cieślar G, Strzelczyk J, Kasperczyk S, Sieroń-Stoltny K, Wiczkowski A, et al. Influence of cryogenic temperatures on inflammatory markers in patients with ankylosing spodylitis. Pol J Environ Stud 2010;19:167-75.

9. Banfi G, Melegati G, Barassi A, Dogliotti G, d'Eril GM, Dugue B, et al. Effects of whole-body cryotherapy on serum mediators of inflammation and serum muscle enzymes in athletes. J Thermal Biol 2009;34:55-9.

10. Bonomi FG, De Nardi M, Fappani A, Zani V, Banfi G. Impact of different treatment of whole-body cryotherapy on circulation parameters. Arch Immunol Ther Exp 2012;60(2):145-50.

11. Nowotny J. Podstawy fizjoterapii, cz. 2. Kraków: Kasper 2007; p. 116.

12. Machalski R, Szalewska D, Hansdorfer-Korzon R. Ocena ryzyka zastosowania krioterapii ogólnoustrojowej u pacjentów z uregulowanym nadciśnieniem tętniczym. Nadciśn Tętn 2013;17(3):235-44.

13. Suszko R. Krioterapia ogólnooustrojowa. Rehabil Med. 2003;7:67.

14. Stanek A, Ćeślar G, Sieroń A. Terapeutyczne zastosowanie krioterapii w praktyce klinicznej. Baln Pol 2007;2:34-45.

15. Fricke R, Hoffmeister K, Nobbe T, Knauer G. Sprint after 2-min whole body exposure at $-110^{\circ} \mathrm{C}$. Schriften Band 1999;12:166-7.

16. Westerlund T, Smolander J, Uusitalo-Koskinen A, Mikkelsson M. The blood pressure responses to an acute and long-term whole-body cryotherapy $\left(-110^{\circ} \mathrm{C}\right)$ in men and women. J Therm Biol 2004;29:285-90.

17. Lubkowska A. Zastosowanie krioterapii w chorobach przewlekłych. Fam Med Primary Care Rev 2013;15(2):233-9. 